\title{
Proposing a Definition and a Framework of Organisational Sustainability: A Review of Efforts and a Survey of Approaches to Change
}

\author{
Rodrigo Lozano ${ }^{1,2}$ (D) \\ 1 Department of Engineering and Sustainable Development, University of Gavle, 80176 Gavle, Sweden; \\ rodrigo.lozano@hig.se; Tel.: +46-734618356 \\ 2 Organisational Sustainability, Ltd., Cardiff CF116EQ, UK
}

Received: 22 March 2018; Accepted: 10 April 2018; Published: 12 April 2018

\begin{abstract}
Organisations (civil society, companies, and public-sector organisations (PSOs)) have been instrumental in driving sustainability. In the last five years, there has been an increasing interest in organisational sustainability, where the importance of sustainability's dimensions depends on an organisation's nature and purpose. A large body of literature on organisational sustainability has focused on companies, followed by education institutions, in particular higher education. Limited, yet increasing, attention has been directed to PSOs and other civil society organisations. Although there have been some attempts to define a sustainable organisation, there is still a need to define and establish the principles of how organisations can address and contribute to sustainability. The sustainability efforts in the different types of organisations were reviewed and then analysed in this paper by using hermeneutics. This was complemented with a survey on sustainability changes. The survey was sent to a database of 1574 contacts from different organisations. In addition, 106 anonymous links were sent out. From the total list of emails, 118 full responses were obtained, with 39 from civil society (37 from higher education and 2 NGOs), 66 corporations, and 13 PSOs. This research distils the key system elements of the efforts in each of the organisations in order to synthesise and propose a definition and a conceptual framework of organisational sustainability. These can help organisations understand where their efforts are and how they could better embed sustainability into their systems, thus contributing to the well-being of societies and the environment for this generation and future ones.
\end{abstract}

Keywords: organisations; sustainability; civil society; public sector organisations; companies

\section{Introduction}

Sustainable development and sustainability have appeared as concepts to help address the negative economic, environmental, and social impacts in this generation and future ones [1,2] through a holistic perspective [3,4]. Organisations (civil society, companies, and public sector organisations (PSOs)) have been instrumental in driving sustainability [5-7]. In the last lustrum, there has been an increasing interest in organisational sustainability see [6,7], where the importance of sustainability's dimensions depends on an organisation's nature and purpose [8].

Some examples of organisational sustainability include: individuals-organisation-global environment relations [9]; organisational culture within the context of corporate sustainability [10,11]; initiatives to embed sustainability into companies [12-14]; organisational change management for sustainability $[15,16]$; and links between assessment and reporting and organisational change management [17-19]. However, most sustainability efforts have focussed on "techno-centric" [11,20] 
or managerial ploys [21] with little, yet increasing, consideration on organisational systems or change processes [22].

A large body of literature on organisational sustainability has focused on companies, e.g., [6,21-25], followed by education institutions, in particular higher education, e.g., [26,27]. Limited, yet increasing, attention has been directed to PSOs and other civil society organisations $[19,28-30]$. There have been only a few papers comparing the types of organisations, e.g., Blanco-Portela et al. [31] comparison of drivers for and barriers to change between higher education institutions (HEIs) and companies.

Although there have been some attempts to define sustainable organisations [32,33], there is still a need to define and establish the principles of how organisations address and contribute to sustainability. This paper is aimed at distilling the key system elements of the efforts and contribution to sustainability of organisations in order to synthesise and propose a definition and a conceptual framework of organisational sustainability.

The paper is structured in the following way: Section 2 presents organisations; Section 3 reviews sustainability efforts of organisations; Section 4 provides a discussion and presents a definition and framework of organisational sustainability; and Section 5 offers concluding remarks.

\section{Organisations}

Organisations are an integral part of modern societies [34]. They are subsystems of a larger environmental system [35,36], which have boundaries between the inside and the outside of the organisation [34]. Organisations provide jobs in society [35], and they represent new types of social forms that have rights, capacities, and resources that are independent of those of its individual members [34].

Organisations are usually divided into, as discussed by Holliday, Schmidheiny, \& Watts [5]: civil society (including society at large, education institutions, and nongovernmental organisations); companies (small, medium, large, national, international, and transnational); and public sector organisations (local, regional, and national). There are other types of organisations, e.g., public-private partnerships, but for the purposes of clarity in this paper, the previous division is used.

Organisations are complex social systems with sets of interrelated units engaged in joint problem-solving to accomplish a goal or objective [36-39], and to create value and acceptable outcomes for stakeholders [39]. Organisations have differentiated functions (the hierarchy and labour division) [36]. They are composed of individuals and groups with interactions and mutual interdependences amongst them and with the organisation, which affect their informational, emotional, and behavioural attitudes [40]. Organisations have inextricably multiple, nonlinear, connected processes, units, values, norms, behaviours, groups, and individuals, affecting, and being affected by, each other, with myriad balancing feedback processes [41-43].

Organisations are affected by forces and conditions that operate beyond their boundaries, which affect their ability to acquire and use resources to create value [39]. Such external forces can complement internal forces to increase competitive advantage [44]. Some authors, e.g., [33,34,43] consider organisations as open systems, i.e., they exchange resources (e.g., energy, materials, labour, money, and information) with others organisations; while other authors, e.g., [44,45] have considered them to be stand-alone units or islands, or closed systems. However, organisations are semi-open (or semi-closed) systems, where some resources enter (e.g., employees when they arrive to work, raw materials, and energy); some resources exit (e.g., emissions and effluents, waste energy, products and by-products, employees when their work is finished); and some remain in the system (e.g., infrastructure, patents, organisation secrets, intellectual property, and organisational routines and behaviours) [40]. The elements, structure, interdependences, interactions, and interconnectedness within an organisation and to other organisations, as well as the importance of boundaries between parts of an organisation and between organisations; and the roles of individuals within and across the boundaries can be understood with the help of systems theory [37]. 
The study and management of change is most relevant in organisations, since it addresses the time dimension by providing a dynamic perspective to sustainability [46-49]. Organisational change aims to move from the current state to one that is more desirable [50], ranging from minor to radical changes $[38,51,52]$. It is fairly easy to identify organisational changes once they have occurred, more difficult to analyse them whilst they are on-going, and even more difficult to predict their direction and tempo [53]. Change represents an opportunity that must be anticipated, prepared for, and managed [54]. Changes in organisations are complex [51], continuous, iterative, and uncertain [55]. The rate of change is dependent on the organisations' context, nature, and external events.

It should be noted that no company, or organisation, is an island [4]. Any organisation must balance the needs of multiple stakeholders [56,57], which can be internal (e.g., stockholders and employees, including management) and external (e.g., customers, suppliers, banks, the environment, and government) $[56,58,59]$.

\section{Methods}

The sustainability efforts in the three types of organisations were analysed using hermeneutics [60-62], which allows a researcher to understand and critically discern between blind and enabling prejudices [63]. The hermeneutical analysis depends on the experience of the interpreter [64], where the whole has to be understood from its individual elements and their connections with each other, while at the same time the individual elements create the whole $[60,64-66]$. In this case, the author of this paper has experience working and publishing on the three types of organisations. In addition, the author has undertaken studies in engineering, social sciences, economy, governance, and business. The analysis in this paper was aimed at looking for: the goals and objectives of the organisations; their system and elements; the sustainability efforts or tools used by the organisations; and their change processes.

Given the increasing interest, but the limited number of papers published in change management for sustainability, the review was complemented with a survey focusing on this topic. The survey was applied using the online survey tool Qualtrics [67]. The data collection took place from August 2016 to February 2017. The survey consisted of five sections: (1) Organisation characteristics, including country of origin and size; (2) Role of respondent within the organisation; (3) Sustainability questions (on a 1-5 Likert scale), such as the importance of economic, environmental, and social issues, as well as the influence of stakeholders; (4) Drivers to change; and (5) Challenges and lessons learnt. The results were analysed using descriptive statistics.

The survey was sent to a database of 1574 contacts from different organisations obtained directly from the database of the Global Reporting Initiative (GRI) list of organisations. In addition, 106 anonymous links were sent out. Two reminders were sent out, one in September 2016 and the second in October 2016. From the total list of emails, 178 emails bounced back as not valid. From the total of 1680 contacts, 118 full responses were obtained, with 39 from civil society (37 from higher education and 2 NGOs), 66 corporations, and 13 PSOs.

\section{Limitations of the Methods}

Due to limitations in size of a journal paper, each organisation and its contribution to sustainability is presented in a concise form. Other important caveats included threats to reliability and validity [68]. In this paper, reliability was mainly affected by observer error and bias, since hermeneutics is based on the interpretation, standpoints, experiences, and the understanding of the researcher [69]. In this case, these were framed by the author's holistic, systems-thinking, and long-term approaches to sustainability and organisations. Validity for this paper was influenced by research on the organisations' contributions' sustainability. The conclusions are, therefore, bound by this context.

The survey may not have offered a complete model of sustainability in organisations. The number of respondents (118) may not allow a complete generalisation to all types of organisations. The organisations that answered may have created a self-selection bias, since they were part of 
the GRI database and decided to answer the survey as discussed by [68,70]. The generalisability of results to all organisations may be limited to the application of a nonrandom sampling procedure and the focus on companies listed in the GRI Disclosure Database with additional input from personal contacts and "snowballing" methods. A nonresponse bias may be caused by companies from sectors which were contacted but refused to complete the survey. Generalisability could be improved by a study based on a randomly selected sample drawn from the total number of organisations active in sustainability.

The majority of the PSOs were selected from the GRI Disclosure Database, which might have skewed their answers to being positive about sustainability.

\section{Organisations' Sustainability Efforts}

Organisations in civil society, companies, and PSOs contexts have been instrumental in driving sustainability [5] and increasing their sustainable value [33]. According to Soyka [8], the importance of the economic, environmental, and social dimensions of sustainability depends on the nature and purpose of the organisation. It should be noted that the time dimension [1,2] is not considered in this approach, which affects organisations depending on their rate of change.

Several initiatives have been developed to encourage sustainable consumption and industrial practices [1], such as the ones discussed by Robèrt and colleagues [12,13] and Lozano [14]. Although there have been some proposals for how to integrate sustainability in organisations, the models have limitations and do not describe how to achieve the integration [33].

On their progress towards sustainability, organisations will go through a process where aligned individuals, groups, and the organisation congruently learn and modify their mental models and actions and collaborate with their stakeholders internally and externally [40]. An organisational culture in which values, norms, and principles encourage behaviours that are sensitive to environmental and social issues is necessary to develop sustainable organisations [32].

Two explicit definitions of sustainable organisations have been identified. Leon [32] proposed a sustainable organisation to be "... an ethic and authentic economic entity that develops the appropriate structures and plans in order to become capable of achieving the objectives defined at the economic, environmental and social levels and to ensure its growth through a rational resource allocation." For Rodríguez-Olalla \& Avilés-Palacios [33], organisational sustainability is " ... a multidimensional phenomenon that focuses on maintaining results, generating knowledge, building capacity, establishing experiences with partners, and producing services and products based on the concepts of efficiency and effectiveness." Although the definitions provide a base for organisational sustainability, they are limited in explaining its principles, elements, relations to stakeholders, and commonalities and specificities in the different organisations when addressing and contributing to sustainability.

Incorporating, integrating, and implementing sustainability in organisations is a complex and multidimensional process since: (1) there is no clear definition of sustainability in organisations [33]; (2) it involves several approaches, theoretical and practical, for the inclusion of sustainability as an organisational value [33,40]; (3) it comprises various organisational levels and attitudes [33,40]; (4) it entails myriad feedback processes [16]; (5) it must maintain results, generate knowledge, build capacity, establish experiences with partners, and produce products and/or services based on efficiency and effectiveness [33]; (6) it addresses the organisation system elements, the four dimensions of sustainability, and the organisation's stakeholders [14]; and (7) it is affected by change processes [15,71].

The following sections provide an overview of the goals, systems, and sustainability efforts and contributions by organisations in civil society, company, and PSOs. It should be noted that, in some cases, much has been written about the organisations, but for the sake of clarity in this paper the discussions have been kept concise. 


\subsection{Civil Society Organisations' (CSOs') Contributions to Sustainability}

Civil society organisations (CSOs) include: educational institutions, religious organisations, nongovernmental organisations (NGOs), and nonprofit organisations. From these, research on sustainability has taken place mostly on the first one, with limited research on the second one, and extremely limited or no research being undertaken on the other ones.

\subsubsection{Higher Education Institutions' Contributions to Sustainability}

Higher education institutions (HEIs) are the pinnacle of the academic system and directly involved in the global knowledge network [72]. They can serve as a proxy for other education institutions. HEIs are organisations dedicated to increasing awareness, knowledge, skills, and values of future professionals [73], future decision-makers, entrepreneurs, and leaders [74,75], and to achieve this, they do it through education and research.

During the last fifteen years, there have been a number of universities engaging with sustainable development [76,77]. According to UNESCO [78], "Education for Sustainable Development (ESD) is aimed at fostering the acquisition of knowledge, skills, attitudes, and values to shape a sustainable future. This includes teaching and learning, e.g., climate change, poverty reduction, and sustainable consumption, participatory teaching, and the promotion of sustainability competencies. ESD is focused on complementing technological solutions, political regulation, and financial instruments, with changes in thinking and action."

Some of the efforts of ESD in HEIs have included: involvement in regional development [26]; reduction of greenhouse gas emissions [79]; water conservation activities [80]; academic leadership commitment via the inclusion of SD in their mission and vision statements [81]; the signing of declarations, charters, and partnerships [27,82,83]; environmental management systems [84,85]; research on sustainability [86]; incorporating SD into curricula [76,87-90]; and the publication of sustainability reports $[18,91]$.

Even though every HEI is unique, all of them present the same characteristic system [75]. The system is comprised of education, research, operations, outreach, assessment and reporting, collaboration with other universities, making SD an integral part of the institutional framework, on-campus life experiences, and "Educate-the-Educators" programmes [27,73], as well as with its stakeholders, including academic directors (e.g., deans, rector, president, directors of department, and directors of divisions), the professors (in the undergraduate and postgraduate courses), researchers, staff, and students [75].

Figure 1 shows the results for the elements of the higher education system covered in sustainability reports on a 5-point Likert scale, where it can be seen that the most addressed elements (in order of importance) are campus operations, campus experiences, institutional framework, education, research, outreach, and collaboration [18]. Figure 2 shows the results of an exploratory literature review carried out by Lozano et al. [27] who undertook an analysis of 62 journal articles from the leading journals on HESD and found that: (1) the highest number of papers (41) focused on education (including curricula, pedagogies, competences, and educating-the-educators); (2) a high number focused on campus operations (15), policy (14), outreach (14), and assessment and reporting (13); (3) some papers focused on research (9) and change management (9); and (4) fewer papers focused on on-campus experiences (2). It should also be noted that 31 of the articles focused only on one of the elements, 21 on two elements, 3 on three elements, 3 on four, 2 on five, 1 on six, and 1 on all the elements. This shows that sustainability has been incorporated into HEIs' systems in a compartmentalised way, i.e., generally focusing on one or two elements. 


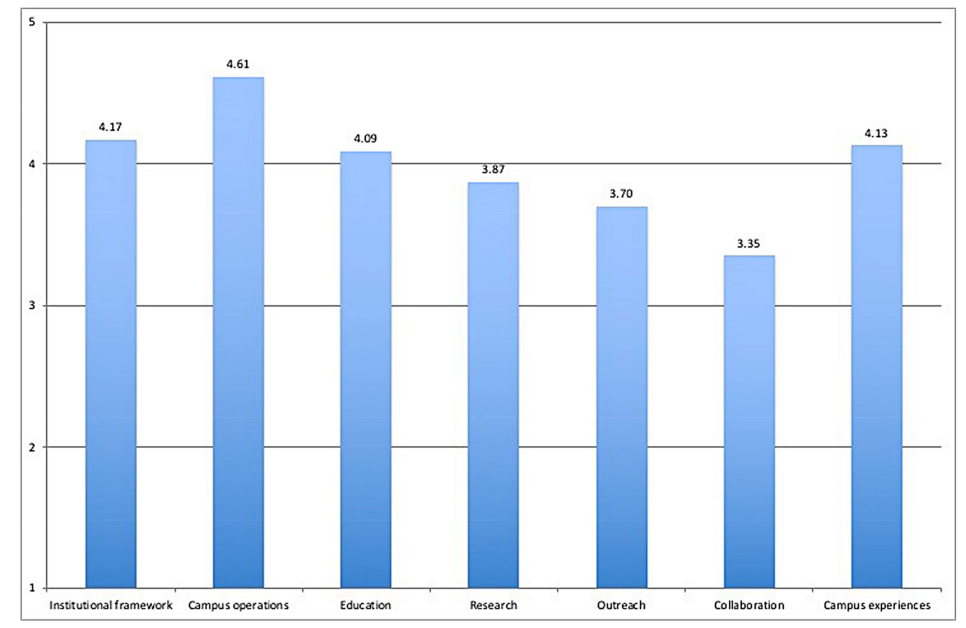

Figure 1. Survey results for the elements of the higher education system covered in sustainability reports (on a 5-point Likert scale). Source: [18].

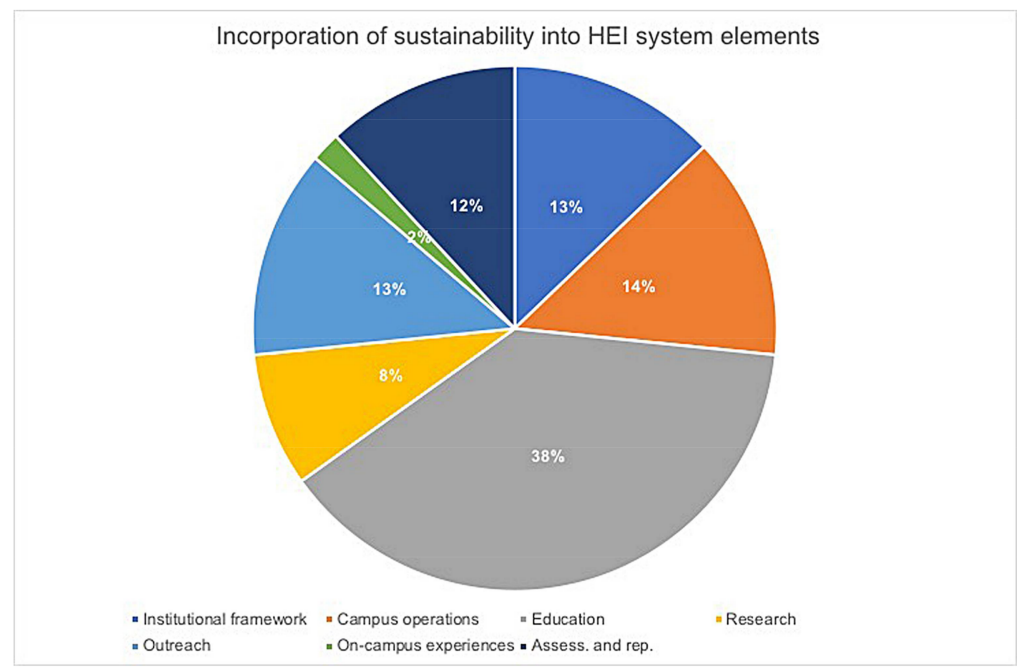

Figure 2. Incorporation of sustainability in the HEI system elements. Source: [27].

During the last ten years, research on organisational change management in HEIs has been increasing, for example, in the areas of: the evolution of a campus sustainability network [92]; the implementation of an SD policy [93]; the role of accreditation in fostering change towards sustainability [94]; drivers and barriers for implementing SD in higher education [31,95,96]; incorporation and institutionalisation into HEIs' systems (including barriers to change and how to overcome them) [75]; the complexities of organisational change for sustainability [97]; and the link between sustainability reporting and organisational change management [18].

\subsubsection{Religious Organisations' Contributions to Sustainability}

According to Beckford [98], religious organisations focus on worship, prayer, meditation, teaching, healing, and spiritual well-being. They share much in common with other organisations, and yet have characteristics that make them unique. They produce sacred knowledge, sacramental acts, transcendental experiences, prophecies, worship and meditation, healing rituals, rites of passage, religious ethics, and social welfare programs.

One of the first instances where the term "sustainable society" was used was in 1974 at the World Council of Churches [99]. Accordingly, a sustainable society is defined by four principles: (1) social 
stability; (2) food supply, carrying capacity, and biodegradation; (3) reduction of nonrenewable resource use; and (4) human activities that have little or no impact on the global climate. A recent development in religious organisations contributing to sustainability was the Papal encyclical letter [100]. Nonetheless, there has been little academic research on these organisations' contributions to sustainability.

\subsection{Corporations' Contributions to Sustainability}

Corporations (also referred to as firms, enterprises, businesses, and companies) are organisations where their associated individuals are, at least in Western countries, legally, in power and liability, separated from their owners [101,102]. Conventionally, corporations produce and sell goods and services for a profit $[56,103,104]$. Their main objective is to generate a satisfactory level of profit for their legal owners $[58,105,106]$.

A growing number of companies have been recognising the relations and interdependences of the economic, environmental, and social dimensions $[103,107]$, for satisfying the needs of today's societies without compromising the needs of tomorrow's societies [108], and integrating sustainability into their strategic and operational decision-making processes [109]. However, integrating sustainability principles into a company's system represents significant challenges, especially due to their complexity and the multidimensional issues [110].

A number of authors have proposed Corporate Sustainability (CS) as a way to address these interdependences. Dyllick \& Hockerts [23] based their definition of CS on the Brundtland Report's [108] definition, but replacing the term 'society' with 'firm'. Siebenhüner and Arnold [111] highlighted that in order for a company to become more sustainability-orientated, they should make changes that include the introduction of resource-efficient technologies and sustainability reporting schemes, while providing sustainable products, services, and product-service combinations. CS must include the effect of management practices on employee physical and psychological well-being [35]. Lozano [14] defined CS as corporate activities that proactively seek to contribute to sustainability equilibria, including the economic, environmental, and social dimensions of today, as well as their interrelations within and throughout the time dimension whilst also addressing the company's system.

Lozano and colleagues [14,112] proposed the following parts of the system in the context of sustainability (depending on the nature of the corporation, research and development may be part of operations and production, management and strategy, or organisational systems):

- Operations and production, including technologies, materials, energy sources, and product development, with closed-loop manufacturing combined with resource efficiency and effectiveness;

- Management and strategy, including productivity, investment and profit, business values and attitudes, objectives, vision and mission, strategies, products, and programmes, transparency, and ethics in corporate decision-making, and stakeholder engagement, participation, and management;

- Organisational systems, such as people, culture, leadership styles, management skills and learning, problem-solving approaches, structures, systems, human resources and development, change management, and innovation;

- Governance, including ownership, the board of directors, institutional framework, and policies;

- Supply chains, taking into consideration the supply chain (i.e., outbound and inbound logistics and transportation), the customers, and consumers, through purchasing, advertising, promotional policies, procedures, and related activities; and

- Assessment and communication, including reporting, risk disclosures (products, operations, construction, and resource utilisation), and accountability.

Figure 3 shows the perception of the links between sustainability reporting and the PSOs system elements, where the elements that are mostly covered (in order of importance) are the institutional 
framework, public management and strategy, public processes and services, collaboration with other organisations, procurement and marketing, and organisational systems.

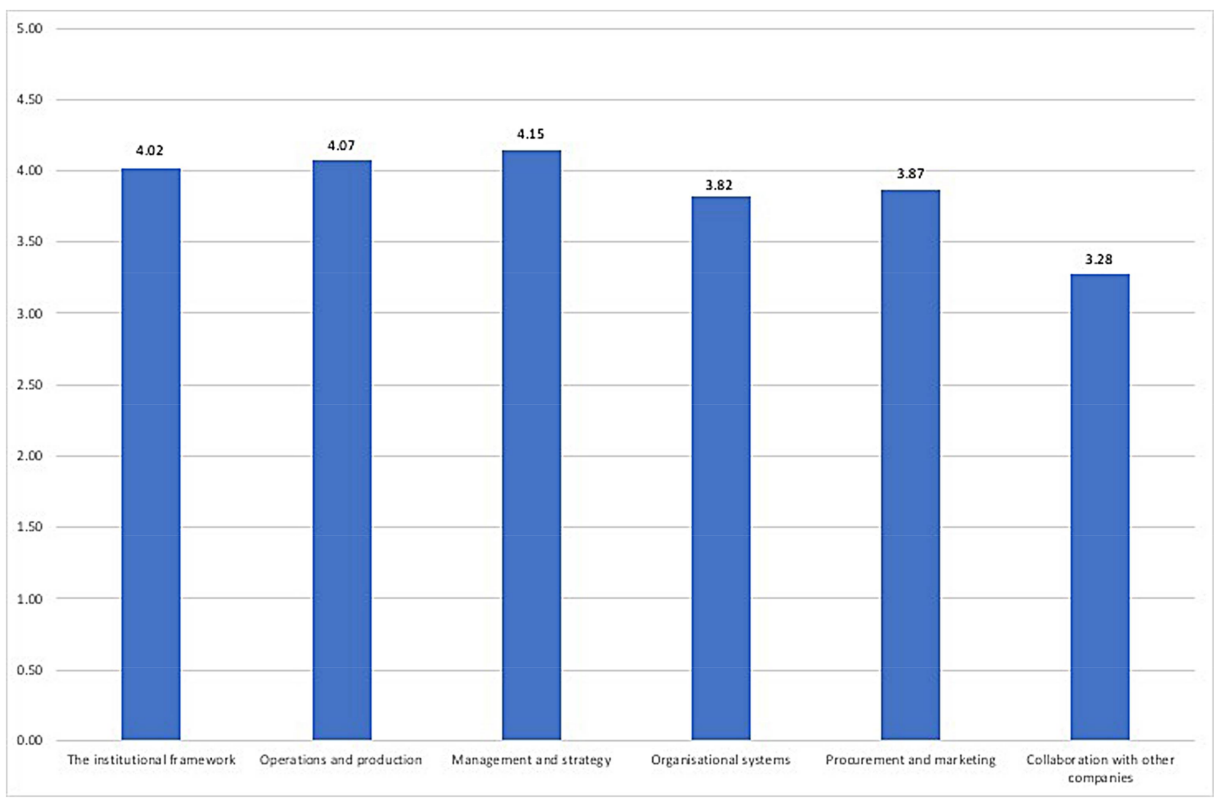

Figure 3. Survey results for the elements of the organisational system covered in sustainability reports by companies. Source: [17].

A number of initiatives, tools, and approaches have been developed by and for companies to engage with sustainability [14]. This includes tools and approaches such as corporate citizenship, corporate social responsibility, design for the environment, eco-efficiency, environmental management systems, Factor X, green chemistry, industrial ecology, life cycle assessment, sustainability reporting, The Natural Step, and the Triple Bottom Line. These tools and approaches have focused principally on "hard" technocentric issues, such as reducing impacts, or improving efficiencies and effectiveness [14], often for individual processes or firms [113], and managerial ploys, which tend to neglect issues such as the company's culture, the supply chain, and the interactions between the company system's elements and the four dimensions of sustainability [22].

In recent years, a new body of literature has appeared that has focused on organisational change management for sustainability. The authors in this field have proposed the use of change theory to better address "soft" issues (such as values, visions, philosophies, policies, employee empowerment, and change management practices) $[71,114,115]$. This has included: intraorganisational differences [116]; change processes [22]; drivers for change [16,71]; barriers to change [15]; upper management initiatives [111]; culture [10,11,117]; and the links between sustainability reporting and organisational change management [17].

\subsection{Public Sector Organisations' (PSOs') Contributions to Sustainability}

According to the OECD [118], PSOs are any organisation that is under government control and that develops public goods or services, according to the Classification of the Functions of Government (COFOG). They are major employers, providers of services, and consumers of resources [119] associated to significant aspects and impacts in the sustainability of the organisation. The public sector represents an important part of international economic activities [120,121]; for example, it accounts for about $20 \%$ of Gross Domestic Product in the UK [122]. The government-whether central, regional, or local-has different roles such as owner, funder, regulator, or purchaser of services provided by a PSO [123]. PSOs 
provide combinations of products and services that benefit society, e.g., teaching children or defending the country from military threats [8].

The public sector influences all other sectors given their size and related activities [121]. It includes services that are provided as public goods, that are wholly or partly funded by taxation, and are managed through governance arrangements that involve some degree of public accountability and political control or influence [122].

Although the term PSO points to public sector as opposed to private sector [123], in recent years, the boundaries between the public and private sectors have become less clear, with organisations such as the quasi-nongovernmental public bodies $[122,124]$.

According to Soyka, many PSOs have been focusing on becoming more sustainability-oriented [8]. Some of the sustainability efforts undertaken by PSOs include: the adoption of social and environmental reports by Italian local authorities [125]; voluntary sustainability reporting based on the Global Reporting Initiative (GRI) Sustainability Reporting Guidelines [29]; environmental disclosure practices in annual reports [126]; environmental reporting practices [30]; performance measurement practice within government departments in Australia [127]; and disclosure practices of sustainability information by European local governments [128]. Despite these advances, PSOs are still lagging behind in SR [28-30], when compared to, for example, companies or higher education institutions.

Domingues et al. [19] proposed a system for PSOs that is comprised of: institutional framework; public processes and services; public management and strategy; organisational systems; procurement and communication; and collaboration with other organisations. Figure 4 shows the perception of the links between sustainability reporting and the PSOs' system elements, where the elements that are mostly covered (in order of importance) are the institutional framework, public management and strategy, public processes and services, collaboration with other organisations, procurement and marketing, and organisational systems.

Research can be found on organisational change, such as managers' performance appraisal and reward systems in PSOs of the central public administration [129], a customer-oriented model for organisational change [130], and transformational leadership and different change management approaches [131]; however, there has been little to no research focusing particularly on organisational change management for sustainability in PSOs, with the exception of Domingues et al. [19] studying the interactions of sustainability reporting and organisational change management.

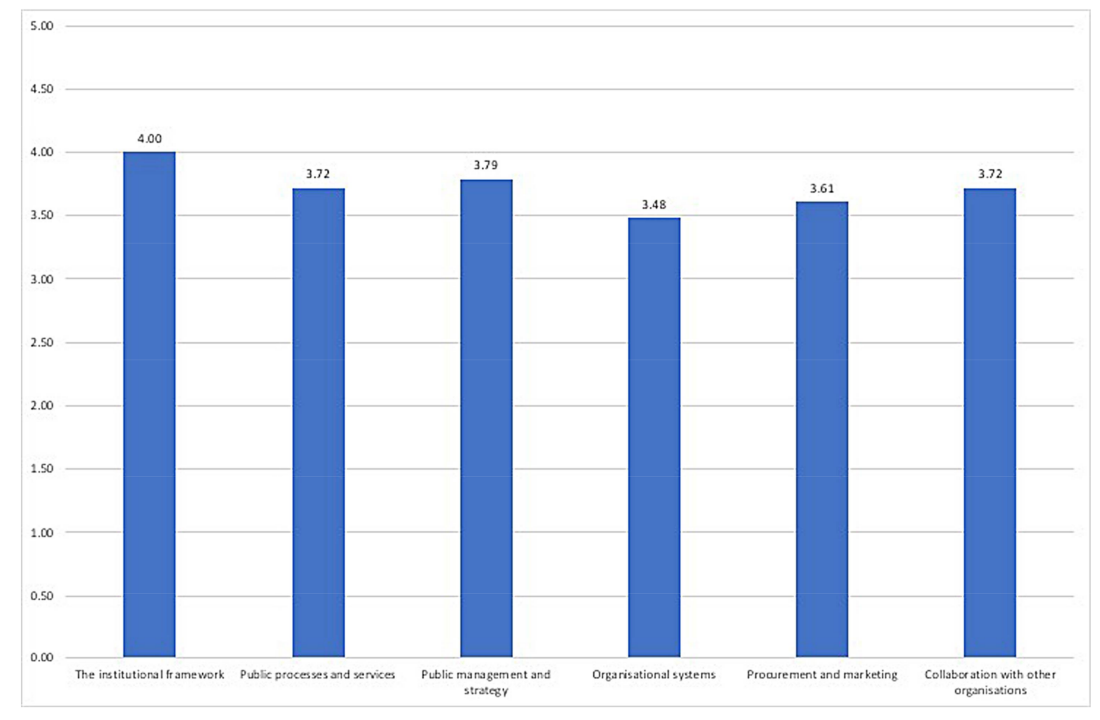

Figure 4. Survey results for the elements of the organisational system covered in sustainability reports by PSOs. Source: [17]. 


\subsection{Organisations' Sustainability Efforts Discussion}

Table 1 shows a comparison of organisational sustainability approaches, where it can be seen that the three types of organisations share some similarities, such as operations and production, collaboration (or outreach) internally and externally, and assessment and reporting. The institutional framework is present in PSOs and civil society organisations, and implicit in governance in companies (which is broader and thus should be used). Civil society has procurement and marketing, whereas companies have supply chains; since the latter is broader it should be used. Companies and PSOs have management and strategy and organisational systems, which are not explicitly indicated in HEIs, except through on-campus life experience as part of organisational systems. HEIs also have strategy and management that should be added to the system. Civil society, particularly HEIs, have education (including "educate-the-educators" programmes) and research, whereas PSOs have public processes and services. These could be integrated into a term called "service provision". HEIs have on-campus life experience, but this could be considered organisational systems, and research that could be relabelled as "research and development".

Table 1. Comparison of organisational sustainability goals and systems.

\begin{tabular}{|c|c|c|c|c|}
\hline & \multicolumn{2}{|c|}{ Civil Society } & \multirow{2}{*}{ Companies } & \multirow{2}{*}{ PSOs } \\
\hline & HEIs & Religious Based & & \\
\hline Goal & Education and Research & Social Well-Being & Profit Generation & Public Services \\
\hline System & $\begin{array}{ll}\text { - } & \text { Education } \\
\text { - } & \text { Research } \\
\text { - } & \text { Operations } \\
\text { - } & \text { Outreach } \\
\text { - } & \text { Assessment and reporting } \\
\text { - } & \text { Collaboration with } \\
\text { - } & \text { other universities } \\
\text { - } & \text { Onstitutional framework } \\
\text { - } & \text { 'Educate-the-Educators' } \\
& \text { programmes. }\end{array}$ & Not studied yet & $\begin{array}{ll}\text { - } & \text { Operations and production } \\
\text { - } & \text { Management and strategy } \\
\text { - } & \text { Governanisational systems } \\
\text { - } & \text { Supply chain } \\
\text { - } & \text { Assessment } \\
\text { - } & \text { and communication } \\
& \text { Collaboration. }\end{array}$ & $\begin{array}{ll}\text { - } & \text { Institutional framework } \\
\text { - } & \text { Public processes } \\
\text { and services } \\
\text { - } & \text { Public management } \\
\text { and strategy } \\
\text { - } & \text { Organisational systems } \\
\text { - } & \text { Procurement } \\
\text { - } & \text { and communication } \\
& \text { other organisations. }\end{array}$ \\
\hline
\end{tabular}

\section{Survey Results}

The review in the previous section was complemented with a survey on sustainability changes with 118 respondents. The results show: the types of organisations, their time working with sustainability; publication of sustainability reports; their sustainability impacts; the stakeholders' sensitivity; their sustainability driving forces; and their sustainability engagement.

Table 2 shows the organisation size. As can be seen in that table, most organisations are large (more than 1000 employees), with some small organisations (e.g., in companies and civil society). Alonso-Almeida et al. [132] argued that size plays a key role in a company's decision to engage with sustainability; however, Lozano et al. [17] showed that this has only a minor role. The role of size in other organisations has not yet been fully discussed.

Table 2. Organisation size (in percentage of the number of organisation type).

\begin{tabular}{ccccc}
\hline & All & Civil Society & Companies & PSOs \\
\hline $1-49$ & $12 \%$ & $8 \%$ & $15 \%$ & $8 \%$ \\
$50-249$ & $8 \%$ & $13 \%$ & $6 \%$ & $0 \%$ \\
$250-499$ & $8 \%$ & $10 \%$ & $5 \%$ & $15 \%$ \\
$500-999$ & $10 \%$ & $15 \%$ & $6 \%$ & $15 \%$ \\
$1000-4999$ & $30 \%$ & $33 \%$ & $29 \%$ & $39 \%$ \\
$>5000$ & $31 \%$ & $18 \%$ & $39 \%$ & $23 \%$ \\
Do not know & $1 \%$ & $3 \%$ & $0 \%$ & $0 \%$ \\
\hline
\end{tabular}


Table 3 highlights that most organisations have been working for more than five years with sustainability ( $84 \%$ of all the organisations, $77 \%$ of civil society, $85 \%$ of companies, and $100 \%$ of PSOs). Few organisations have been working with sustainability for less than one year (3\% of companies, civil society, and all, with $0 \%$ of PSOs). This shows that the vast majority of respondents have considerable experience in working with sustainability issues.

Table 3. Time working with sustainability (in percentage of the number of organisation type).

\begin{tabular}{ccccc}
\hline & All & Civil Society & Companies & PSOs \\
\hline Less than 1 year & $3 \%$ & $3 \%$ & $3 \%$ & $0 \%$ \\
Between 1 and 3 years & $5 \%$ & $8 \%$ & $5 \%$ & $0 \%$ \\
Between 3 and 5 years & $8 \%$ & $13 \%$ & $8 \%$ & $0 \%$ \\
Between 5 and 10 years & $22 \%$ & $21 \%$ & $26 \%$ & $8 \%$ \\
Between 10 and 15 years & $25 \%$ & $15 \%$ & $24 \%$ & $54 \%$ \\
More than 15 years & $37 \%$ & $41 \%$ & $35 \%$ & $38 \%$ \\
\hline
\end{tabular}

Table 4 shows that most organisations have published some sort of sustainability reports. This is the case in companies (77\%) and PSOs (62\%). The exception is from civil society where only $33 \%$ have done so.

Table 4. Publication of sustainability reports by the organisations (in percentage of the number of organisation type).

\begin{tabular}{ccccc}
\hline & All & Civil Society & Companies & PSOs \\
\hline Yes & $61 \%$ & $33 \%$ & $77 \%$ & $62 \%$ \\
No & $39 \%$ & $67 \%$ & $23 \%$ & $38 \%$ \\
\hline
\end{tabular}

Figure 5 highlights that the organisations agree (53\% of all, $62 \%$ of civil society, $52 \%$ of companies, and $31 \%$ of PSOs) or strongly agree (34\% of all, $26 \%$ of civil society, $35 \%$ of companies, and $54 \%$ of PSOs) that they are proactively engaging with sustainability. It should be noted that PSOs have the highest percentage of agreement, with civil society and companies agreeing less.

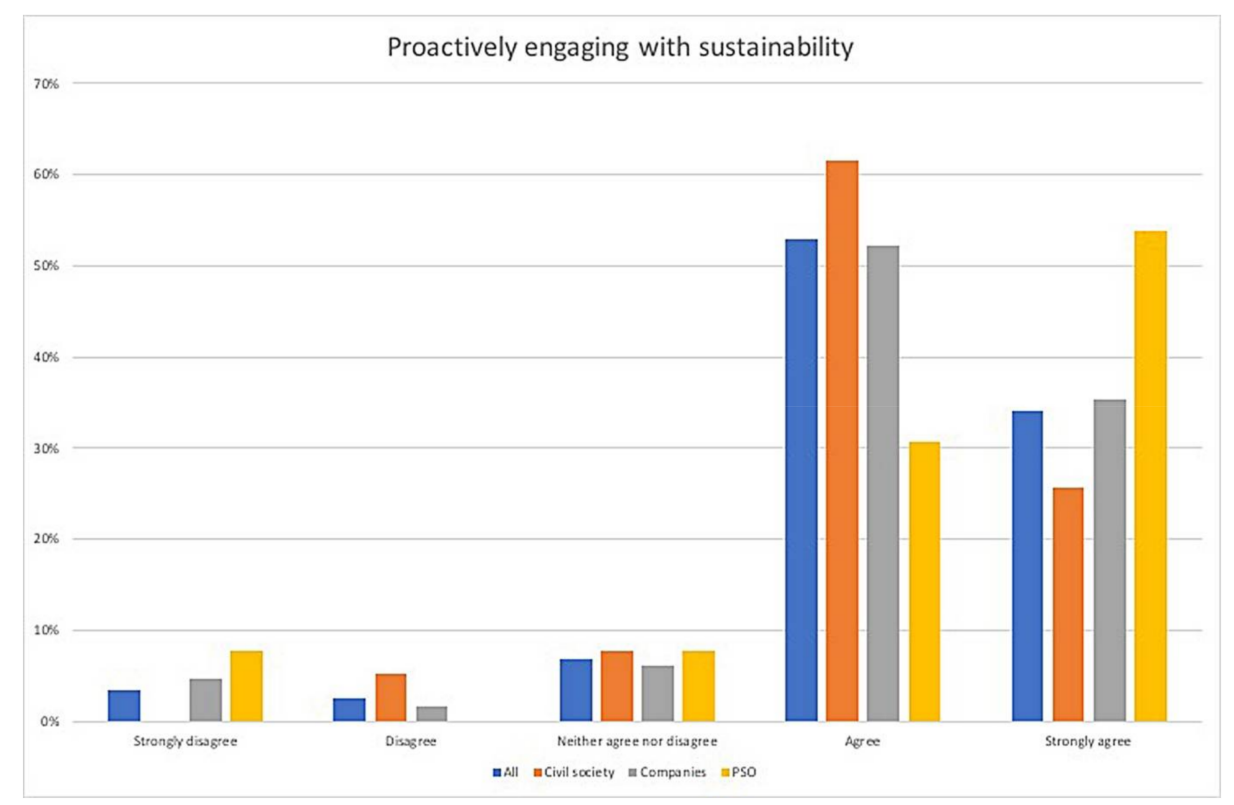

Figure 5. Proactive sustainability engagement by the organisations (in percentage of the number of organisation type). 
Figure 6 shows the perceptions of the respondents of the sustainability impacts of their organisations. As it can be seen, the economic impacts are high on companies and civil society (68\% and $56 \%$, respectively), and less on PSOs (38\%). The environmental impacts are high on PSOs $(77 \%)$, companies $(59 \%)$, and less on civil society ( $41 \%)$. The social impacts are high on civil society $(80 \%)$, companies $(65 \%)$, and PSOs (46\%).

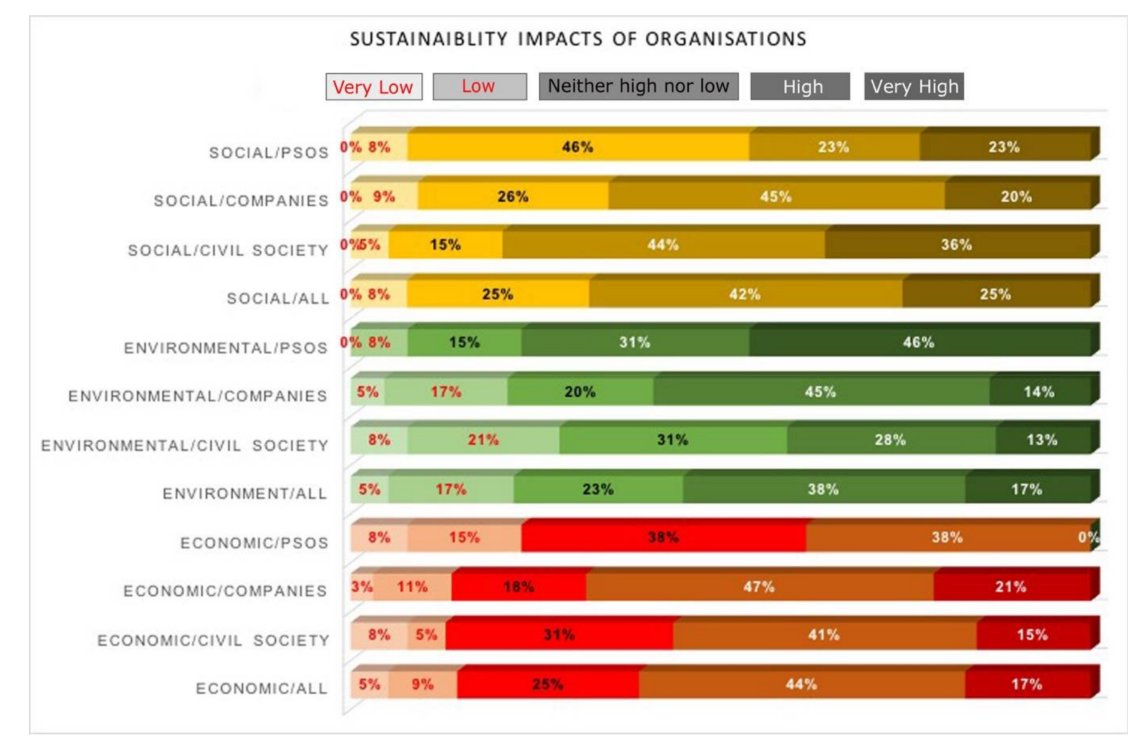

Figure 6. Perceptions of sustainability impacts from the organisations (in percentage of the number of organisation type).

Figure 7 shows that the organisations' stakeholders agree or strongly agree that they are sensitive to negative impacts of unsustainable society ( $85 \%$ of PSOs, $82 \%$ of companies, $78 \%$ of all organisations, $72 \%$ of civil society). This shows that organisations are aware that their actions will affect stakeholders.

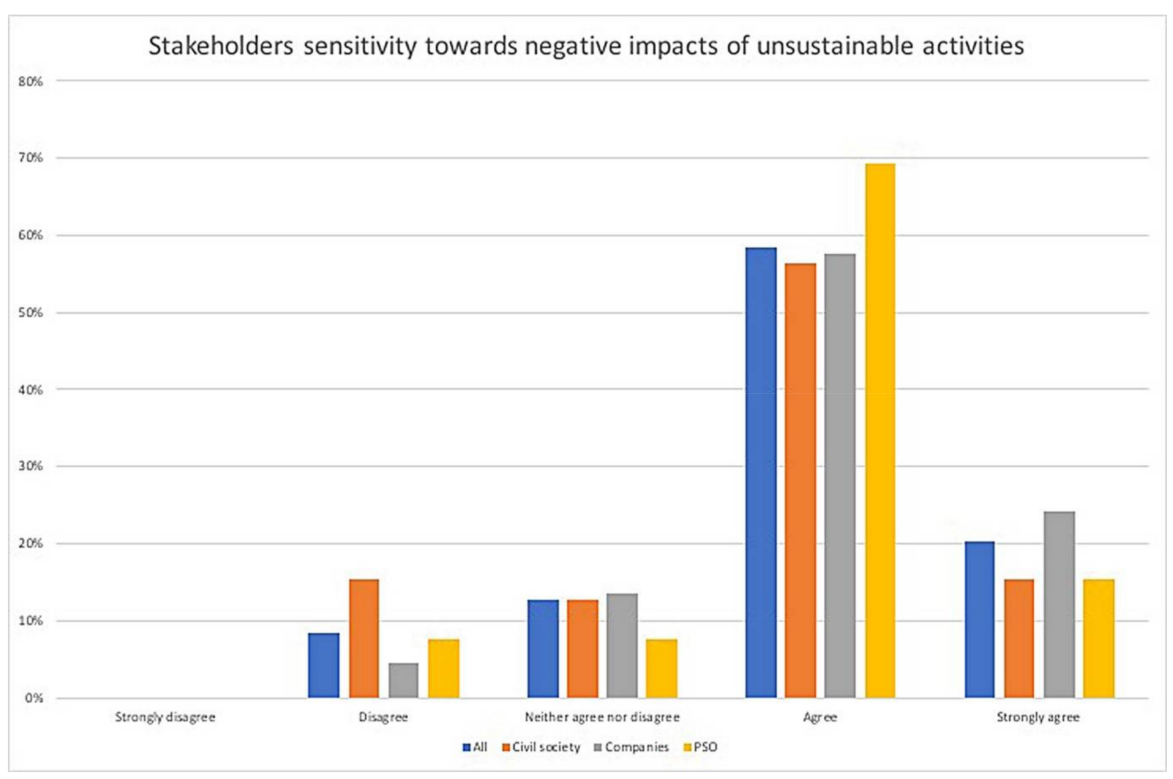

Figure 7. Organisations' stakeholders' sensitivity towards negative impacts of unsustainable activities.

Figure 8 shows the sustainability driving forces of organisations. For a detailed discussion of different driving forces, please refer to [16-19,71]. As it can be seen, they are, in general, equally 
by external stimuli and internal factors ( $47 \%$ of all, $38 \%$ of civil society, $54 \%$ of companies, and $38 \%$ of PSOs), followed by mainly by internal factors, but with some external stimuli (32\% of all, 38\% of civil society, $28 \%$ of companies, and $31 \%$ of PSOs). It should be noted that in PSOs, the highest percentage was equally by external stimuli and internal factors, followed by the same percentage of mainly internal factors, but with some external stimuli and mainly by external stimuli, but with some internal factors with $31 \%$ each. It should be noted that very few organisations indicated either solely by internal factor or solely by external stimuli.

Table 5 highlights the importance of sustainability dimensions, where the economic one is most important to companies, then to civil society organisations, and less to PSOs. The environmental dimension is more important to PSOs, followed by companies, then by civil society. The social dimension is more important to civil society than to companies and PSOs.

Table 5 also shows that they have been working with sustainability more than five years. Changes are driven equally by internal factors and external stimuli, followed by mainly internal factors but some external stimuli, and then mainly by external stimuli but with some internal factors. Most organisations that completed the survey have published a sustainability report, with the exception of civil society. PSOs indicate that their perception of sustainability impacts is lower than those of civil society or companies. This may be due to social issues being embedded into their normal activities, or because they understand sustainability as relating to the environment. This should be further explored.

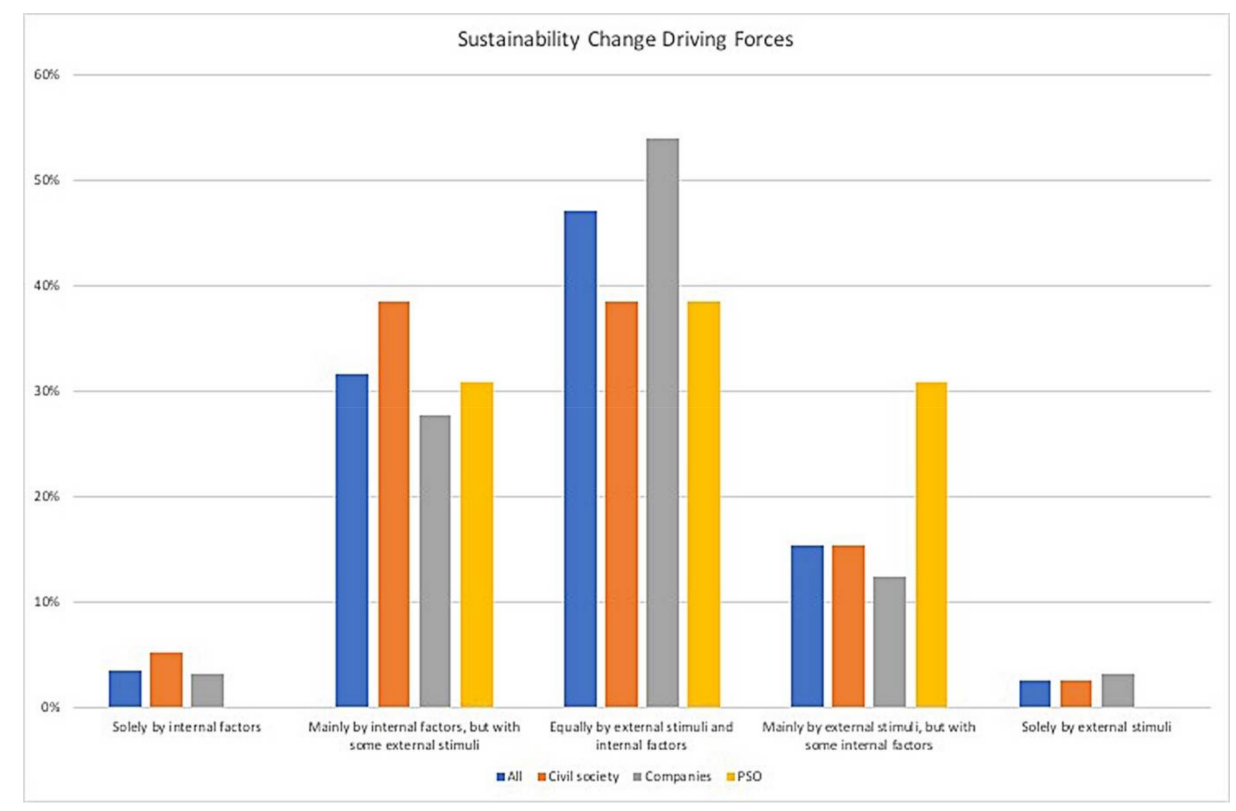

Figure 8. Sustainability driving forces (in percentage of the number of organisation type).

Table 5. Comparison of organisational sustainability approaches.

\begin{tabular}{|c|c|c|c|c|}
\hline \multicolumn{2}{|c|}{ Approach } & \multirow{2}{*}{$\begin{array}{c}\text { Civil Society } \\
56 \%\end{array}$} & \multirow{2}{*}{$\begin{array}{c}\text { Companies } \\
68 \%\end{array}$} & \multirow{2}{*}{$\begin{array}{c}\text { PSOs } \\
38 \%\end{array}$} \\
\hline Perception of & Economic & & & \\
\hline sustainability & Environmental & $41 \%$ & $59 \%$ & $77 \%$ \\
\hline impacts & Social & $80 \%$ & $65 \%$ & $46 \%$ \\
\hline \multicolumn{2}{|c|}{ Change processes } & $\begin{array}{l}\text { Equally internal and } \\
\text { external, and by } \\
\text { mainly internal but } \\
\text { with some external }\end{array}$ & $\begin{array}{l}\text { Equally internal and } \\
\text { external, followed by } \\
\text { mainly internal but } \\
\text { with some external }\end{array}$ & $\begin{array}{l}\text { Equally internal } \\
\text { and external }\end{array}$ \\
\hline \multicolumn{2}{|c|}{ Publication of sust. reports } & $33 \%$ & $77 \%$ & $62 \%$ \\
\hline \multicolumn{2}{|c|}{ More than 5 years working with sust. } & $56 \%$ & $59 \%$ & $92 \%$ \\
\hline
\end{tabular}




\section{Discussing Organisations' Contributions to Sustainability}

There have been many efforts aimed at incorporating sustainability in organisations, with several initiatives created to encourage sustainable consumption and industrial practices [1], such as the ones discussed by Robert and his colleagues [12,13] and Lozano [14]. Incorporating, integrating, and implementing sustainability in organisations is a complex and multidimensional process [110].

As the previous sections highlight, there have been many efforts in companies [6,21-25], followed by those in education institutions, in particular higher education ones e.g., [26,27]. Limited, yet increasing, attention has been directed to PSOs and other civil society organisations [19,28-30]. In general, addressing and contributing to sustainability by each type of organisation has been done in a compartmentalised way, where each organisation has proposed its own definition and application of the concept. This has provided considerable results, but at the same time it has created divisions between the actors, despite most of them being considered as organisations. Most efforts have been focused on one type of organization, with the exception of the comparison of drivers for and barriers to sustainability change in companies and HEIs by Blanco-Portela et al. [31]. Although there have been some attempts to define a sustainable organisation [32,33], there is still a need to define and establish the principles of how organisations can address and contribute to sustainability.

From the previous sections, a set of four concepts and twelve principles can be distilled for a sustainable organisation, as shown in Table 6.

Table 6. Concepts and principles of a sustainable organization.

\begin{tabular}{ccl}
\hline Concept & Principles \\
\hline Context & - $\begin{array}{l}\text { Is part of its wider system (social and environmental); } \\
\text { - }\end{array}$ & Contributes to making society more sustainable; \\
\hline - & $\begin{array}{l}\text { Has resources that enter, i.e., inputs, (raw material and energy, which have economic } \\
\text { and environmental value, and human resources who enter the organisation); } \\
\text { resources that exit, i.e., outputs, (products and services, with economic and } \\
\text { environmental values and human resources who leave the organisation); and } \\
\text { resources that are recovered; }\end{array}$ \\
& - $\begin{array}{l}\text { Has resources and infrastructure; } \\
\text { Has human resources, including individuals and, depending on the organisation's } \\
\text { size, groups, that have culture, values, attitudes, and norms; } \\
\text { Generates waste that needs to be recycled or disposed of; }\end{array}$ \\
\hline Processes & - $\quad \begin{array}{l}\text { Entails a system, comprised of operations and production, management and strategy, } \\
\text { governance, organisational systems, assessment and reporting, and service provision; } \\
\text { Is affected by change processes and their rate of change, which are affected by the } \\
\text { type of organisation and external events; }\end{array}$ \\
\hline Interactions & $\begin{array}{l}\text { Is affected by a supply chain (from procurement to marketing); } \\
\text { Affects and is affected by its stakeholders (internal and external), including the } \\
\text { environment; and } \\
\text { Has interdependences and collaborates within the organisation and to } \\
\text { other organisations. }\end{array}$ \\
\hline
\end{tabular}

It should be noted that some authors use the term "sustainable organisation" [32,33]. This implies that the organisation is sustainability, which is not possible since sustainability is a dynamic ideal that can always be improved [2]. It will be better to label this term as "organisational sustainability", defined as the contributions of an organisation to sustainability, which includes how it is integrated into its system elements and processes.

The aforementioned arguments can be integrated into Figure 9, which has the following components: (I) Inputs, including material resources and energy, economic value, (intrinsic) 
environmental value, and human resources (that enter the company); (II) System elements (operations and production, management and strategy, organisational systems, governance, and assessment and reporting) and change processes, which link the inputs and outputs and generate waste; (III) Stakeholders (internal, interconnecting, and external); (IV) Outputs, including products and services, environmental value, and human resources (that exit the company); and (V) Purpose fulfilment, based on Resource Efficiency. It should be noted that the organisation has tangible and intangible resources, and part of the products and services may come back through recovery as material resources or energy.

The colours in Figure 9 indicate the different flow paths: White refers to material resources and energy transformed through the processes to products and services; Red refers to the economic value of the input materials and their increase to output economic value, through Yellow purpose fulfilment (based on resource efficiency and effectiveness); Lime indicates the environmental value of the inputs and outputs, as well as recovery; Blue refers to the human resources that enter and exit the company, which are modified by the system elements and change; Purple highlights the time dimension; Green font indicates the environment (internal and external); Blue font highlights the supply chain; Red font indicates the resources and infrastructure; and Grey shows the waste generated by the processes.

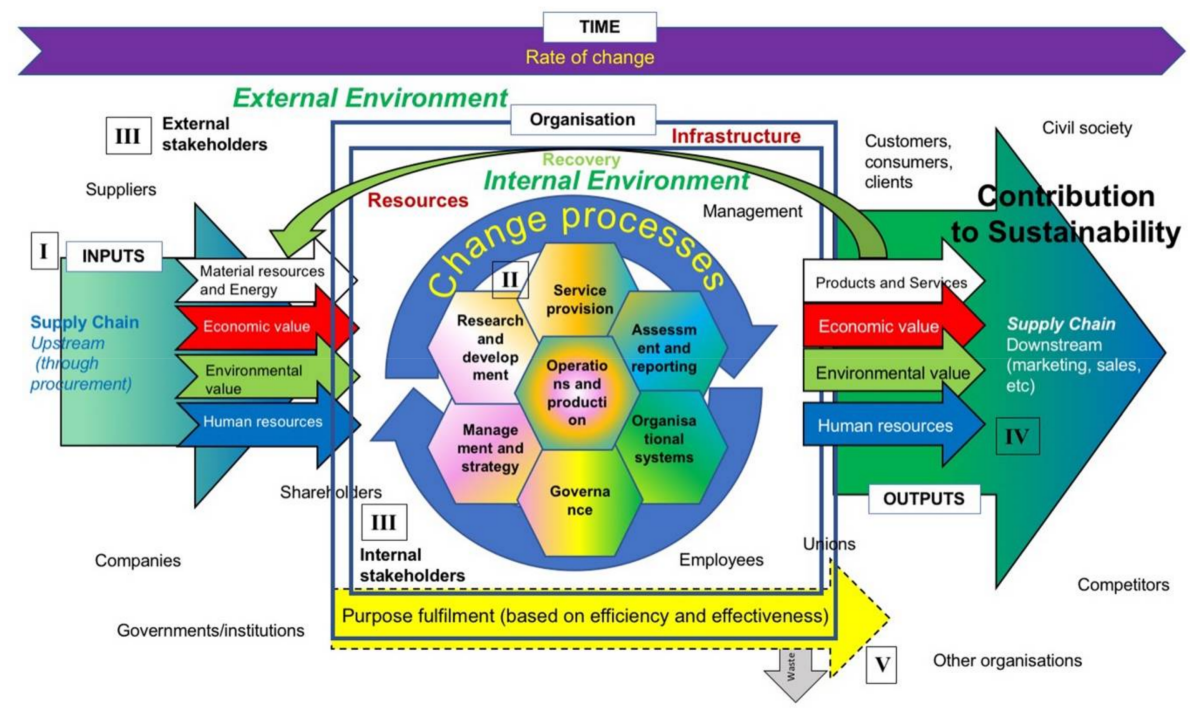

Figure 9. Organisational sustainability framework.

\section{Conclusions}

Organisations (civil society, companies, and public-sector organisations (PSOs)) have been instrumental in driving sustainability. Although a number of efforts have been taken by a number of organisations, these have been usually within each sector and seldom comparing them against other sectors. A large body of literature on organisational sustainability has focussed on companies, followed by education institutions, in particular higher education. Limited, yet increasing, attention has been directed to PSOs and other civil society organisations. There have been only a small number of papers comparing the types of organisations, e.g., the comparison of drivers for and barriers to change between higher education institutions (HEIs) and companies.

Although there have been some attempts to provide a definition of a sustainable organisation or how organisations can contribute to sustainability, there is still a need to define and establish the principles of a sustainable organisation. The paper reviews the sustainability efforts in civil society, company, and public-sector organisations. The research distils the key system elements of the efforts in each of the organisations in order to synthesise and propose a definition and a conceptual framework of organisational sustainability, which cover the principles, the goals and objectives of the organisations, their system, sustainability efforts or tools used by the organisations, and change processes. 
Organisational sustainability can thus be proposed to be: "The contributions of the organisation to sustainability equilibria, including the economic, environmental, and social dimensions of today, as well as their interrelations within and throughout the time dimension (i.e., the short-, long-, and longer-term). This entails the continuous incorporation and integration of sustainability issues in the organisation's system elements (operations and production, strategy and management, governance, organisational systems, service provision, and assessment and reporting), as well as change processes and their rate of change. The system elements and change processes transform the inputs (in regard to material and resources that have economic, environmental, and social value) into outputs (products, services, and waste, with their economic, environmental, and social value). These fulfil the organisation's goal or objective, based on resource efficiency and effectiveness. The organisation is affected by the organisation's nonhuman and human resources (i.e., individuals, groups, culture, values, attitudes, and norms), its infrastructure, its supply chain (upstream and downstream), and the interactions with its stakeholders (internal, interconnecting, and external)".

The definition and framework can help organisations understand where the emphases of their efforts are and how they could better embed sustainability into their systems, thus contributing to the well-being of societies and the environment for this generation and future ones, as well as organisations' survival opportunities. It should be noted that in this discussion, all companies are organisations, but all organisations are not companies.

The definition and framework can also help compare sustainability efforts by organisations of different types. It should be noted that the significance of the system elements is dependent on the type and context of the organisation, for example, for a manufacturing company operations and production would be more important, whereas service provision would be more significant for a PSO.

A number of topics need to be further researched, for example: (1) the processes of incorporation and institutionalisation of sustainability in different organisations and their systems; (2) the links between the system elements; (3) the systems, roles, and contributions of public-private partnerships; (4) a comparison of different organisations and their size; (5) the contribution of PSOs to sustainability; (6) the contribution of religious-based organisations to sustainability and their system elements; (7) the correlation between organisations' size, time working with sustainability, and publication of sustainability reports; and (8) the sustainability efforts of organisations that are not listed in the GRI database.

Acknowledgments: I would like to thank the reviewers' comments that have helped me improve the paper. I would also like to thank Angela Carpenter, Francisco J. Lozano, Maria Barreiro Gen, and Lea Fobbe for their suggestions in refining the paper.

Conflicts of Interest: The author declares no conflict of interest.

\section{References}

1. Batista, A.A.S.; de Francisco, A.C. Organizational sustainability practices: A study of the firms listed by the Corporate Sustainability Index. Sustainability 2018, 10. [CrossRef]

2. Lozano, R. Envisioning Sustainability three-dimensionally. J. Clean. Prod. 2008, 16, 1838-1846. [CrossRef]

3. Hjorth, P.; Bagheri, A. Navigating towards sustainable development: A system dynamics approach. Futures 2006, 38, 74-92. [CrossRef]

4. Lozano, R.; Huisingh, D. Inter-linking issues and aspects in Sustainability Reporting. J. Clean. Prod. 2011, 19, 99-107. [CrossRef]

5. Holliday, C.O.J.; Schmidheiny, S.; Watts, P. Walking the Talk: The Business Case for Sustainable Development; Greenleaf Publishing: Sheffield, UK, 2002.

6. Jennings, P.D.; Zandbergen, P.A. Ecologically Sustainable Organizations: An Institutional Approach. Acad. Manag. Rev. 1995, 20, 1015-1052.

7. Danter, K.J.; Griest, D.L.; Mullins, G.W.; Norland, E. Organizational change as a component of ecosystem management. Soc. Nat. Resour. 2000, 13, 537-547.

8. Soyka, P.A. Creating a Sustainable Organization; FT Press: Upper Saddle River, NJ, USA, 2012. 
9. Edwards, M. Organisational Transformation for Sustainability: An Integral Metatheory; Routledge: London, UK, 2009.

10. Linnenluecke, M.K.; Griffiths, A. Corporate sustainability and organizational culture. J. World Bus. 2010, 45, 357-366. [CrossRef]

11. Linnenluecke, M.K.; Russell, S.V.; Griffiths, A. Subcultures and sustainability practices: The impact on understanding corporate sustainability. Bus. Strateg. Environ. 2009, 18, 432-452. [CrossRef]

12. Robèrt, K.-H. Tools and concepts for sustainable development, how do they relate to a general framework for sustainable development, and to each other? J. Clean. Prod. 2000, 8, 243-254. [CrossRef]

13. Robèrt, K.-H.; Schmidt-Bleek, B.; Aloisi de Larderel, J.; Basile, G.; Jansen, J.L.; Kuehr, R.; Price Thomas, P.; Suzuki, M.; Hawken, P.; Wackernagel, M.; et al. Strategic sustainable development-Selection, design and synergies of applied tools. J. Clean. Prod. 2002, 10, 197-214. [CrossRef]

14. Lozano, R. Towards better embedding sustainability into companies' systems: An analysis of voluntary corporate initiatives. J. Clean. Prod. 2012, 25, 14-26. [CrossRef]

15. Lozano, R. Are Companies Planning their Organisational Changes for Corporate Sustainability? An Analysis of Three Case Studies on Resistance to Change and their Strategies to Overcome it. Corp. Soc. Responsib. Environ. Manag. 2013, 20, 275-295. [CrossRef]

16. Lozano, R. A Holistic Perspective on Corporate Sustainability Drivers. Corp. Soc. Responsib. Environ. Manag. 2015, 22, 32-44. [CrossRef]

17. Lozano, R.; Nummert, B.; Ceulemans, K. Elucidating the relationship between Sustainability Reporting and Organisational Change Management for Sustainability. J. Clean. Prod. 2016, 125. [CrossRef]

18. Ceulemans, K.; Lozano, R.; Alonso-Almeida, M. Sustainability Reporting in Higher Education: Interconnecting the Reporting Process and Organisational Change Management for Sustainability. Sustainability 2015, 7, 8881-8903. [CrossRef]

19. Domingues, A.R.; Lozano, R.; Ceulemans, K.; Ramos, T.B. Sustainability reporting in public sector organisations: Exploring the relation between the reporting process and organisational change management for sustainability. J. Environ. Manag. 2017, 192, 292-301. [CrossRef] [PubMed]

20. Doppelt, B. Leading Change toward Sustainability: A Change-Management Guide for Business, Government and Civil Society; Greenleaf Publishing: Sheffield, UK, 2003.

21. Henriques, A.; Richardson, J. The Triple Bottom Line. Does It All Add up? Earthscan: London, UK, 2005.

22. Lozano, R. Orchestrating Organisational Changes for Corporate Sustainability. Greener Manag. Int. 2012, 43-64. [CrossRef]

23. Dyllick, T.; Hockerts, K. Beyond the business case for corporate sustainability. Bus. Strateg. Environ. 2002, 11, 130-141. [CrossRef]

24. Schaltegger, S.; Burrit, R.L. Corporate sustainability. In The International Yearbook of Environmental and Resource Economics 2005/2006; Folmer, H., Tietenberg, T., Eds.; Edward Elgar: Cheltenham, UK, 2005; pp. 185-222.

25. Tschopp, D.J. Corporate social responsibility: A comparison between the United States and the European Union. Corp. Soc. Responsib. Environ. Manag. 2005, 12, 55-59. [CrossRef]

26. Dlouhá, J.; Huisingh, D.; Barton, A. Learning networks in higher education: Universities in search of making effective regional impacts. J. Clean. Prod. 2013, 49, 5-10. [CrossRef]

27. Lozano, R.; Ceulemans, K.; Alonso-Almeida, M.; Huisingh, D.; Lozano, F.J.; Waas, T.; Lambrechts, W.; Lukman, R.; Hugé, J. A review of commitment and implementation of sustainable development in higher education: Results from a worldwide survey. J. Clean. Prod. 2015, 108. [CrossRef]

28. Dumay, J.; Guthrie, J.; Farneti, F. Gri Sustainability Reporting Guidelines for Public and Third Sector Organizations. Public Manag. Rev. 2010, 531-548. [CrossRef]

29. Guthrie, J.; Farneti, F. GRI Sustainability Reporting by Australian Public Sector Organizations. Public Money Manag. 2008, 28, 361-366. [CrossRef]

30. Lodhia, S.; Jacobs, K.; Park, Y.J. Driving Public Sector Environmental Reporting. Public Manag. Rev. 2012, 14, 631-647. [CrossRef]

31. Blanco-Portela, N.; Benayas, J.; Pertierra, L.R.; Lozano, R. Towards the integration of sustainability in Higher Education Institutions: A review of drivers of and barriers to organisational change and comparison against those found of companies. J. Clean. Prod. 2017, 166, 563-578. [CrossRef]

32. Leon, R.-D. From the Sustainable Organization to Sustainable Knowledge-Based Organization. Econ. Insights Trends Chall. 2013, 2, 63-73. 
33. Rodríguez-Olalla, A.; Avilés-Palacios, C. Integrating Sustainability in Organisations: An Activity-Based Sustainability Model. Sustainability 2017, 9, 1072. [CrossRef]

34. Scott, W.R.; Davis, G.F. Organization: Overview, 2nd ed.; Elsevier: New York, NY, USA, 2015; Volume 16.

35. Pfeffer, J. Building Sustainable Organizations: The Human Factor. Acad. Manag. Perspect. 2010, $24,34-45$. [CrossRef]

36. Porter, L.W.; Lawler, E.I.; Hackman, J.R. Behavior in Organizations; McGraw-Hill: New York, NY, USA, 1975.

37. Stacey, R.D. Strategic Management and Organisational Dynamics; Pitman Publishing: London, UK, 1993.

38. Rogers, E.M. Diffusion of Innovations; The Free Press of Glencoe: New York, NY, USA, 1962.

39. Jones, G.R. Organizational Theory, Design, and Change; Pearson Education Limited: Harlow, UK, 2013.

40. Lozano, R. Developing collaborative and sustainable organisations. J. Clean. Prod. 2008, 16, 499-509. [CrossRef]

41. Cyert, R.M.; March, J.G. A behavioural Theory of the Firm; Prentice-Hall Inc.: Upper Saddle River, NJ, USA, 1963.

42. Kotter, J.P. Leading Change; Harvard Business School Press: Boston, MA, USA, 1996.

43. Senge, P.M. The Fifth Discipline: The Art \& Practice of the Learning Organization; Random House Business Books: London, UK, 1999.

44. Gebauer, H.; Worch, H. Absorptive Capacity (of Organizations), 2nd ed.; Elsevier: New York, NY, USA, 2015; Volume 1.

45. Kanter, R.M. The Change Masters; International Thomson Business Press: London, UK, 1999.

46. Drury, D.H.; Farhoomand, A. Innovation diffusion and implementation. Int. J. Innov. Manag. 1999, 3, $133-157$. [CrossRef]

47. Litvin, D. Empires of Profit: Commerce, Conquest and Corporate Responsibility; TEXERE Publishing Limited: London, UK, 2003.

48. Lozano, R. Orchestrating Organisational Change for Corporate Sustainability: Strategies to Overcome Resistance to Change and to Facilitate Institutionalization. Ph.D. Thesis, Cardiff University, Cardiff, UK, 2009.

49. O'Connor, M. Entropy, structure, and organisational change. Ecol. Econ. 1991, 3, 95-122. [CrossRef]

50. Ragsdell, G. Engineering a paradigm shift? An holistic approach to organisational change management. J. Organ. Chang. 2000, 13, 104-120. [CrossRef]

51. Dawson, P. Organizational Change: A Processual Approach; Paul Chapman Publishing Ltd.: London, UK, 1994.

52. Dawson, P. Organizational Change; Elsevier: New York, NY, USA, 2001; pp. 10921-20923.

53. Benne, K.D.; Birnbaum, M. Principles of changing. In The Planning of Change; Bennis, W.G., Benne, K.D., Chin, R., Eds.; Holt, Rinehart and Winston, Inc.: New York, NY, USA, 1969.

54. European Commission. Managing Change; European Commission, Employment \& Social Affairs: Brussels, Belgium, 1998.

55. Pettigrew, A.; Whipp, R. Managing Change for Competitive Success; Blackwell Publishers Ltd.: Oxford, UK, 1991.

56. Freeman, R.E. Strategic Management: Stakeholder Approach; Pitman: Boston, MA, USA, 1984.

57. Hill, C.W.L.; Jones, G.R. Strategic Management: An Integrated Approach; Houghton Mifflin Company: Boston, MA, USA, 2001.

58. Argadoña, A. The stakeholder theory and the common good. J. Bus. Ethics 1998, 17, 1093-1102. [CrossRef]

59. Freeman, R.E.; Wicks, A.C.; Parmar, B. Stakeholder theory and "The Corporate Objective Revisited". Organ. Sci. 2004, 15, 364-369. [CrossRef]

60. Harrington, A. Dilthey, Empathy and Verstehen A Contemporary Reappraisal. Eur. J. Soc. Theory 2001, 4, 311-329. [CrossRef]

61. Heidegger, M. Being and Time; Harper and Row: New York, NY, USA, 1976.

62. Leyh, G. Hermeneutics toward a Constitutional. Am. J. Political Sci. 1988, 32, 369-387. [CrossRef]

63. Bernstein, R.J. From Hermeneutics to Praxis. Rev. Metaphys. 1982, 35, 823-845.

64. Dilthey, W.; Jameson, F. The Rise of Hermeneutics Wilhelm Dilthey. New Lit. Hist. 1972, 3, 229-244. [CrossRef]

65. Gadamer, H.-G. Hermeneutics and Social Science. Philos. Soc. Crit. 1975, 2, 307-316. [CrossRef]

66. Schleiermacher, E.E. Hermeneutics and Critics (Hermeneutik und Kritik); Manfred, F., Ed.; Suhrkamp: Frankfurt am Main, Germany, 1977.

67. Qualtrics Copyright (C) 2014 Qualtrics. Qualtrics and All Other Qualtrics Product or Service Names Are Registered Trademarks or Trademarks of Qualtrics, Provo, UT, USA. Available online: http:/ / www.qualtrics.com (accessed on 22 March 2018). 
68. Saunders, M.; Lewis, P.; Thornhill, A. Research Methods for Business Students; Pearson Education Limited: Harlow, UK, 2007.

69. Heller, A. From Hermeneutics in Social Science toward a Hermeneutics of Social Science. Theory Soc. 1989, 18, 291-322. [CrossRef]

70. Bryman, A. Social Research Methods, 2nd ed.; Oxford University Press: Oxford, UK, 2004; Volume 2.

71. Lozano, R.; von Haartman, R. Reinforcing the Holistic Perspective of Sustainability: Analysis of the Importance of Sustainability Drivers in Organizations. Corp. Soc. Responsib. Environ. Manag. 2017. [CrossRef]

72. Altbach, P.G.; Reisberg, L.; Rumbley, L.E. Trends in Global Higher Education: Tracking an Academic Revolution; UNESCO Pub.: London, UK, 2009.

73. Cortese, A.D. The critical role of higher education in creating a sustainable future. Plan. High. Educ. 2003, 33, $15-22$.

74. Elton, L. Dissemination of innovations in higher education: A change theory approach. Tert. Educ. Manag. 2003, 9, 199-214. [CrossRef]

75. Lozano, R. Incorporation and institutionalization of SD into universities: Breaking through barriers to change. J. Clean. Prod. 2006, 14, 787-796. [CrossRef]

76. Boks, C.; Diehl, J.C. Integration of sustainability in regular courses: Experiences in industrial design engineering. J. Clean. Prod. 2006, 14, 932-939. [CrossRef]

77. Wemmenhove, R.; de Groot, W.T. Principles for university curriculum greening. An empirical case study from Tanzania. Int. J. Sustain. High. Educ. 2001, 2, 267-283. [CrossRef]

78. UNESCO Education for Sustainable Development. Available online: http://en.unesco.org/themes/ education-sustainable-development (accessed on 20 February 2017).

79. Klein-Banai, C.; Theis, T.L. Quantitative analysis of factors affecting greenhouse gas emissions at institutions of higher education. J. Clean. Prod. 2013, 48, 29-38. [CrossRef]

80. Marinho, M.; Gonçalves, M.D.S.; Kiperstok, A. Water conservation as a tool to support sustainable practices in a Brazilian public university. J. Clean. Prod. 2014, 62, 98-106. [CrossRef]

81. Lee, K.-H.; Barker, M.; Mouasher, A. Is it even espoused? An exploratory study of commitment to sustainability as evidenced in vision, mission, and graduate attribute statements in Australian universities. J. Clean. Prod. 2013, 48, 20-28. [CrossRef]

82. Wright, T.S.A. The evolution of environmental sustainability declarations in higher education. In Higher Education and the Challenge of Sustainability: Problematics, Promise, and Practice; Wals, A.E.J., Corcoran, P.B., Eds.; Kluwer Academic Publishers: Dordrecht, The Netherlands, 2004; pp. 7-19.

83. Lozano, R.; Lukman, R.; Lozano, F.J.; Huisingh, D.; Lambrechts, W. Declarations for sustainability in higher education: Becoming better leaders, through addressing the university system. J. Clean. Prod. 2013, 48, 10-19. [CrossRef]

84. Nicolaides, A. The implementation of environmental management towards sustainable universities and education for sustainable development as an ethical imperative. Int. J. Sustain. High. Educ. 2006, 7, 414-424. [CrossRef]

85. Holm, T.; Vuorisalo, T.; Sammalisto, K. Integrated management systems for enhancing education for sustainable development in universities: A memetic approach. J. Clean. Prod. 2015, 106, 155-163. [CrossRef]

86. Hugé, J.; Block, T.; Waas, T.; Wright, T.; Dahdouh-Guebas, F. How to walk the talk? Developing actions for sustainability in academic research. J. Clean. Prod. 2016, 137, 83-92. [CrossRef]

87. Davis, S.A.; Edmister, J.H.; Sullivan, K.; West, C.K. Educating sustainable societies for the twenty-first century. Int. J. Sustain. High. Educ. 2003, 4, 169-179. [CrossRef]

88. Thomas, I. Sustainability in tertiary curricula: What is stopping it happening? Int. J. Sustain. High. Educ. 2004, 5, 33-47. [CrossRef]

89. Abdul-Wahab, S.A.; Abdulraheem, M.Y.; Hutchinson, M. The need for inclusion of environmemtnal education in undergraduate engineering curricula. Int. J. Sustain. High. Educ. 2003, 4, 126-137. [CrossRef]

90. Von Blottnitz, H. Promoting active learning in sustainable development: Experiences from a 4th year chemical engineering course. J. Clean. Prod. 2006, 14, 916-923. [CrossRef]

91. Lozano, R.; Llobet, J.; Tideswell, G. The process of assessing and reporting sustainability at universities: Preparing the report of the University of Leeds. Sostenibilidad Tecnol. Humanismo 2013, 6, 85-112. 
92. Kurland, N.B. Evolution of a campus sustainability network: A case study in organizational change. Int. J. Sustain. High. Educ. 2011, 12, 395-429. [CrossRef]

93. Gudz, N.A. Implementing the sustainable development policy at the University of British Columbia: An analysis of the implications for organisational learning. Int. J. Sustain. High. Educ. 2004, 5, 156-168. [CrossRef]

94. Cooper, S.; Parkes, C.; Blewitt, J. Can accreditation help a leopard change its spots? Social accountability and stakeholder engagement in business schools. Account. Audit. Account. J. 2014, 27, 234-258. [CrossRef]

95. Holmberg, J.; Samuelsson, B.E. Drivers and Barriers for Implementing Sustainable Development in Higher Education. Education for Sustainable Development in Action; Holmberg, J., Samuelsson, B.E., Eds.; UNESCO: Paris, France, 2006.

96. Barth, M. Many roads lead to sustainability: A process-oriented analysis of change in higher education. Int. J. Sustain. High. Educ. 2013, 14, 160-175. [CrossRef]

97. Hoover, E.; Harder, M.K. What lies beneath the surface? The hidden complexities of organizational change for sustainability in higher education. J. Clean. Prod. 2014. [CrossRef]

98. Beckford, J.A. International Encyclopedia of the Social \& Behavioral Sciences, 2nd ed.; Elsevier: New York, NY, USA, 2015; Volume 20.

99. Dresner, S. The Principles of Sustainability; Earthscan Publications Ltd.: London, UK, 2002.

100. Pope Francis Encyclical Letter Laudato Si' of the Holy Father Francis on Care for Our Common Future. Available online: http:/ / w2.vatican.va/content/francesco/en/encyclicals/documents/papa-francesco_ 20150524_enciclica-laudato-si.html (accessed on 16 March 2018).

101. Avi-Yonah, R.S. The Cyclical Transformations of the Corporate Form: A Historical Perspective on Corporate Social Responsibility. SSRN Electron. J. 2005, 30, 767-818. [CrossRef]

102. Diesendorf, M. Sustainability and sustainable development. In Sustainability: The Corporate Challenge of the 21st Century; Dunphy, D., Benveniste, J., Griffiths, A., Sutton, P., Eds.; Allen \& Unwin: Sydney, Australia, 2000; Volume 2, pp. 19-37.

103. CEC. Corporate Social Responsibility: A Business Contribution to Sustainable Development; Commission of the European Communities: Brussels, Belgium, 2002.

104. Demsetz, H. The theory of the firm revisited. J. Law Econ. Organ. 1988, 4, 141-162.

105. Boatright, J.R. Business ethics and the theory of the firm. Am. Bus. Law J. 1996, 34, 217-238. [CrossRef]

106. Radin, M. The endless problem of corporate personality. Columbia Law Rev. 1932, 32, 643-667. [CrossRef]

107. Elkington, J. Cannibals with Forks: The Triple Bottom Line of the 21st Century Business; Capstone Publishing Co.: Oxford, UK, 2002.

108. WCED. Our Common Future; Oxford University Press: Oxford, UK, 1987.

109. Thomas, T.E.; Lamm, E. Legitimacy and Organizational Sustainability. J. Bus. Ethics 2012, 110, 191-203. [CrossRef]

110. Langer, M.E.; Schön, A. Enhancing Corporate Sustainabiliy: A Framework Based Evaluation Tools for Sustainable Development; Forschungsschwerpunkt Nachhaltigkeit und Umweltmanagement, Wirtschaftsuniversität Wien: Vienna, Austria, 2003.

111. Siebenhuner, B.; Arnold, M. Organizational learning to manage sustainable development. Bus. Strategy Environ. 2007, 16, 339-353. [CrossRef]

112. Lozano, R.; Suzuki, M.; Carpenter, A.; Tyunina, O. An Analysis of the Contribution of Japanese Business Terms to Corporate Sustainability: Learnings from the "Looking-Glass" of the East. Sustainability 2017, 9, 188. [CrossRef]

113. Korhonen, J. Should we measure corporate social responsibility? Corp. Soc. Responsib. Environ. Manag. 2003, 10, 25-39. [CrossRef]

114. Dunphy, D.; Griffiths, A.; Benn, S. Organizational Change for Corporate Sustainability; Routledge: London, UK, 2014.

115. Lozano, R. Sustainability inter-linkages in reporting vindicated: A study of European companies. J. Clean. Prod. 2013, 51, 57-65. [CrossRef]

116. Kupers, W.M. Integral Responsibilities for a Responsive and Sustainable Practice in Organization and Management. Corp. Soc. Responsib. Environ. Manag. 2011, 18, 115-137. [CrossRef]

117. Linnenluecke, M.K.; Griffiths, A. Firms and sustainability: Mapping the intellectual origins and structure of the corporate sustainability field. Glob. Environ. Chang. 2013, 23, 382-391. [CrossRef] 
118. OECD. Government at a Glance 2015; OECD Publishing: Paris, France, 2015.

119. GRI. GRI Sector Supplement for Public Agencies Pilot Version 1.0; Global Reporting Initiative: Amsterdam, The Netherlands, 2005.

120. Walker, H.; Brammer, S. The relationship between sustainable procurement and e-procurement in the public sector. Int. J. Prod. Econ. 2012, 140, 256-268. [CrossRef]

121. Ball, A.; Grubnic, S. Sustainability accounting and accountability in the public sector. In Sustainability Accounting and Accountability; Unerman, J., Bebbington, J., O’Dwyer, B., Eds.; Routledge: Oxford, UK, 2007; pp. 243-265.

122. Flynn, N. Public Sector Management; SAGE Publications, Inc.: London, UK, 2012.

123. Meyer, R.E.; Leixnering, S. Public Sector Organizations, 2nd ed.; Elsevier: New York, NY, USA, 2015; Volume 18.

124. Stevenson, A. The Public Sector; Kogan Page Ltd.: London, UK, 2013.

125. Marcuccio, M.; Steccolini, I. Social and environmental reporting in local authorities. Public Manag. Rev. 2005, 7, 155-176. [CrossRef]

126. Lynch, B. An examination of environmental reporting by Australian state government departments. Account. Forum 2010, 34, 32-45. [CrossRef]

127. Adams, C.A.; Muir, S.; Hoque, Z. Measurement of sustainability performance in the public sector. Sustain. Account. Manag. Policy J. 2014, 5, 46-67. [CrossRef]

128. Navarro Galera, A.; de los Ríos Berjillos, A.; Ruiz Lozano, M.; Tirado Valencia, P. Transparency of sustainability information in local governments: English-speaking and Nordic cross-country analysis. J. Clean. Prod. 2014, 64, 495-504. [CrossRef]

129. Azzone, G.; Brophy, M.; Noci, G.; Welford, R.; Young, W. A stakeholder's view of environmental reporting. Long Range Plan. 1997, 30, 699-709. [CrossRef]

130. Chen, C.-K.; Yu, C.-H.; Chang, H.-C. ERA model: A customer-orientated organizational change model for the public service. Total Qual. Manag. Bus. Excell. 2006, 17, 1301-1322. [CrossRef]

131. Van der Voet, J. The effectiveness and specificity of change management in a public organization: Transformational leadership and a bureaucratic organizational structure. Eur. Manag. J. 2014, 32, 373-382. [CrossRef]

132. Alonso-Almeida, M.; Llach, J.; Marimon, F. A Closer Look at the "Global Reporting Initiative" Sustainability Reporting as a Tool to Implement Environmental and Social Policies: A Worldwide Sector Analysis. Corp. Soc. Responsib. Environ. Manag. 2014, 21, 318-335. [CrossRef] 